дается данными о появлении структурных изменений миокарда в диапазоне доз 13-15 Зв. Низкие дозы облучения в основном приводят к функциональным изменениям в работе сердца (изменения кровеносных сосудов, дистрофические нарушения его мышечных волокон и напряженность вегетативной регуляции деятельности), и не исчезают в отдаленные периоды после лучевого воздействия. Реакции сосудистого звена при радиационных нагрузках, относящихся к диапазону малых доз проявляются лишь расширением границ физиологической лабильности вегетативно-сосудистой регуляции и не связаны с органическими изменениями в элементах сосудистой системы. Особенности центрального кровотока у лиц, подвергшихся радиационному воздействию вследствие проживания за контролируемой территории, имеют компенсаторный характер, тогда как наиболее негативные эффекты со стороны гемодинамики проявляются в сосудах среднего и малого диаметра. Стоит отметить также, что такие эффекты наблюдаем при проведении функциональных проб с физической или умственной нагрузкой, тогда как состояние покоя зачастую не обнаруживает особенностей работы сердечнососудистой системы у лиц, подвергшихся радиационному воздействию и жителей относительно экологически чистых зон.

Ключевые слова: ионизируешее изучение, сердечно-сосудистая система, геодинамика.

Zhuravlov Olexandr, Shvaiko Svitlana, Dmytrotsa Olena, Burban Lilia. The Pecurliarities of Cardiovascular System's Reactions on the Effects of Ionizing Radiation. The reactions of cardiovascular system's structures on the effect of radiation factor caused the controversy among scientists for a long time. The heart, in contrast to the vasculature, refers to quite radioresistant organs, which was confirmed by the appearance of myocardium's structural changes in the dose range of 13-15 minutes. The lower radiation doses basically lead to functional changes in work of heart (changes in blood vessels, dystrophic violation of its muscle fibers and tension of autonomic regulation of activity), which do not disappear in the remote period after radiation influence. The reactions of the vascular level during the radiation load, which related to the range of low doses, are manifested only through the expanding boundaries of physiological lability of vegetative-vascular regulation and are not related to organic changes in the elements of the vascular system. The peculiarities of central blood flow in people, who have suffered from the radiation exposure due to residence on controlled territory, have compensatory nature, while the most negative effects of the hemodynamics are manifested in blood vessels with small and medium diameter. It should be also noted, that these effects are observed during the carrying out of functional tests with physical or mental exertion, while the state of rest often does not reveal the specifics of the cardiovascular system in people that suffered from the radiation exposure and inhabitants of relatively environmentally clean areas.

Key words: ionizing radiation, cardiovascular system, geodynamics.

Стаття надійшла до редколегії 14.03.2016 p.

\author{
Оксана Боровець, \\ Володимир Бенедь, \\ Свдокія Решетнік, \\ Станіслав Весельський, \\ Микола Макарчук
}

\title{
Жовчносекреторна функція печінки самок щурів в умовах блокади естрогенових рецепторів тамоксифеном
}

У гострих дослідах на щурах-самках із канюльованою жовчною протокою, які перебували під тіопенталовим наркозом (5 мг/100 г), досліджено вплив тамоксифену (57,2 мкг/100 г) при його одноразовому внутрішньопортальному введенні на жовчносекреторну функцію печінки. За допомогою тонкошарової хроматографії визначено концентрацію жовчних кислот (вільних і кон'югованих із таурином і гліцином) в отриманих впродовж гострих дослідів п’яти півгодинних пробах жовчі.

Ключові слова: жовч, жовчні кислоти, печінка, естрогенові рецептори, тамоксифен.

Постановка наукової проблеми та її значення. Аналіз досліджень цієї проблеми. Епідеміологічні та клінічні дослідження переконливо свідчать, що жовчокам'яна хвороба значно частіше

(С Боровейь О., Бенедь В., Решетнік С., Весельський С., Макарчук М., 2016 
трапляється в жінок, ніж у чоловіків. Для європейців характерне формування жовчних каменів саме холестеролової природи [16]. Фізіологічне збільшення концентрації естрогенів (яке спостерігаємо, наприклад, під час вагітності), а також застосування гормональних контрацептивів і гормон-замісна терапія в постменопаузі призводять до посиленої екскреції холестеролу клітинами печінки, перенасичення ним жовчі й, отже, збільшують ризик виникнення холестеролових жовчних каменів у жінок $[5,7,10,14,17]$. Однак серед чоловіків зростає кількість патологій гепато-біліарної системи, таких як порушення жовчносекреторної функції печінки, жовчнокам'яна хвороба тощо. Це пов'язують з особливостями харчування та іншими екзогенними факторами. Також цікавий той факт, що споживання етанолу суттєво збільшує кількість естрогенових рецепторів у клітинах печінки, що розглядається як можливий механізм фемінізації й розвитку патології печінки при алкоголізмі. Водночас виявлено, що i естрогени (естрадіол), і андрогени (дигідротестостерон), позитивно впливаючи на тканину печінки й обмін у ній жирних кислот, запобігають розвитку неалкогольного жирового гепатозу при високожировій дієті [19].

Ефекти естрогенів на метаболічні, транспортні, секреторні процеси опосередковуються через ядерні рецептори двох типів - ESR1 (а) та ESR2 (ß), які експресуються, зокрема, у тканині печінки [16, 18]. Крім того, дія естрогенів може реалізуватися завдяки активації естрогензалежних кіназ через сполучені 3 G-білками мембранні рецептори (GPR30) $[6,9,12,17,18,19]$. Участь тих чи інших типів рецепторів i, відповідно, механізми впливу естрогенів на жовчносекреторну функцію становлять значний теоретичний $і$ практичний інтерес та обговорюються в науковій літературі $[1,6,9,12,15,17,18,19,20]$. Провідну патогенетичну роль у формуванні холестеролових жовчних каменів відведено ядерним естрогеновим рецепторам ESR1, що свідчить про тривалий транскрипційний механізм дії естрогенів на утворення й секрецію жовчі [8].

Мета роботи - 3'ясування ролі естрогенових рецепторів у регуляції жовчносекреторної функції щурів-самок під час дослідження об’ємної швидкості секреції жовчі та ії жовчнокислотного складу в умовах застосування селективного модулятора ESR1 (a) й ESR2 ( $\beta$ ) рецепторів нестероїдної природи тамоксифену.

Методика. Досліди проведено на білих щурах-самках із масою 180-250 г, у гострих дослідах використано 80 щурів, які перед дослідом були позбавлені їжі на 18-20 год, але мали вільний доступ до води. Усі експерименти з використанням тварин виконано відповідно до Хельсинської декларації (Всесвітня медична асамблея, 1964), Декларації принципів толерантності (28 сесія ЮНЕСКО, 1995), Універсальної декларації по біоетиці та правах людини (ООН, 1997), норм Конвенції про захист прав людини у зв'язку з впровадженням нових біомедичних технологій, прийнятою в 1997 р. в м. Ов'єдо (Іспанія) та підписаною Верховною Радою України у 2002 р., Закону України № 3447 IV «Про захист тварин від жорстокого поводження». Проведені експериментальні дослідження не суперечать загальноприйнятим біоетичним нормам і здійснені з дотриманням відповідних міжнародних положень, які стосуються проведення експериментальних робіт та клінічних досліджень.

Під час гострого досліду тварини перебували під тіопенталовим наркозом (5мг/100г маси тіла тварини), уведеним внутрішньочеревно. Після лапаротомії у відпрепаровану жовчну протоку через надріз iї стінки вводили тонку пластикову канюлю з приєднаною поліетиленовою трубкою, котра з'єднувалась із мікропіпеткою. Упродовж 30 хв після канюлювання жовчної протоки визначали вихідний рівень жовчовиділення шляхом збору трьох 10-хвилинних порцій жовчі. Після цього піддослідним тваринам внутрішньопортально вводили тамоксифен (57,2 мкг на 100 г маси тіла тварини, розчинений у 200 мкл фізіологічного розчину) та естрон (8 мкг на 100 г маси тіла тварини у 200 мкл фізіологічного розчину). Контрольній групі тварин аналогічно вводили відповідний об'єм фізіологічного розчину (200 мкл). Об’єм секретованої жовчі реєстрували кожні 10 хвилин упродовж трьох годин досліду. Інтенсивність секреторної функції печінки оцінювали за середньою об’ємною швидкістю секреції жовчі, котру розраховували за об'ємом жовчі (нл), що продукувалася впродовж однієї хвилини в перерахунку на один грам маси тіла $(н л / 2-х в)$.

У кожній півгодинній збірній пробі, отриманій у гострому досліді жовчі методом тонкошарової хроматографії, визначали якісний і кількісний уміст жовчних кислот (таурохолевої, суміші таурохенодезоксихолевої й тауродезоксихолевої, глікохолевої, суміші глікохенодезоксихолевої та глікодезоксихолевої, вільної холевої, суміші вільних диоксихоланових кислот - хенодезоксихолевої й дезоксихолевої) [2].

Статистичну обробку отриманих результатів проводили із використанням стандартизованих методів варіаційної статистики (8TATI8TICA 6.0) з урахуванням критерію t-Стьюдента. Нормальність розподілу даних оцінювали за допомогою тесту Шапіро-Уілка [3, 4]. 
Виклад основного матеріалу й обгрунтування отриманих результатів дослідження. Середня об'ємна швидкість секреції жовчі в самок щурів після внутрішньопортальної ін'єкції тамоксифену $(57,2$ мкг/100 г) не зазнає статистично значимих змін і складала впродовж 2,5 годин гострого досліду 44,0 $\pm 3,4-35,6 \pm 2,0$ (нл/г/хв). Потрібно зазначити, що в самок, які отримали тамоксифен, нормальна фізіологічна дія ендогенних естрогенів через відповідні внутрішньоклітинні естрогенові рецептори стала неможливою. Це, зі свого боку, мало викликати суттєві зміни в регуляції метаболічних процесів у клітинах печінки.

Тамоксифен (57,2 мкг/100 г, внутрішньопортально) суттєво впливав на концентрацію холатів різних фракцій, визначених нами в пробах жовчі самок щурів (табл. 1). Установлено, що через півгодини після введення тамоксифену концентрація таурохолевої кислоти в жовчі самок щурів збільшується на $16,8 \%$ ( $>00,05)$, у наступній півгодинній пробі - на $25,3 \%(\mathrm{p}<0,01)$, а через півтори години після введення тамоксифену - на 30,7 \% (p < 0,01), через дві години - на 29,6 \% (p < 0,001). Наприкінці досліду концентрація таурохолату в контролі становить $159,7 \pm 6,1$ мг \%, а у тварин, яким внутрішньопортально введено тамоксифен, цей показник сягає 205,2 6,4 мг \%.

Таблиия 1

Концентрація жовчних кислот у жовчі самок щурів (м⿰ \%) після внутрішньопортального введення тамоксифену $(57,2$ мкг/100 г), $(M \pm S D ; n=11)$

\begin{tabular}{|c|c|c|c|c|c|c|c|}
\hline $\begin{array}{r}\text { Пів } \\
\text { пр } \\
\text { дос. }\end{array}$ & $\begin{array}{l}\text { годинні } \\
\text { міжки } \\
\text { ідду, час }\end{array}$ & $\begin{array}{c}\text { Таурохолева } \\
\text { кислота }\end{array}$ & $\begin{array}{c}\text { Таурохено- } \\
\text { дезоксихолева } \\
\text { й } \\
\text { тауродезокси- }\end{array}$ & $\begin{array}{c}\text { Глікохо- } \\
\text { лева } \\
\text { кислота }\end{array}$ & $\begin{array}{c}\text { Глікохено- } \\
\text { дезоксихолева } \\
\text { й } \\
\text { глікодезокси- } \\
\text { холева }\end{array}$ & $\begin{array}{l}\text { Холева } \\
\text { кислота }\end{array}$ & $\begin{array}{c}\text { Хенодезокси- } \\
\text { холева } \\
\text { й } \\
\text { дезоксихолева }\end{array}$ \\
\hline 10.00 & контроль & $177,6 \pm 6,5$ & $99,2 \pm 8,0$ & $92,5 \pm 8,0$ & $36,2 \pm 2,3$ & $16,3 \pm 1,5$ & $7,7 \pm 0,5$ \\
\hline 10.30 & дослід & $207,5 \pm 10,3^{*}$ & $97,1 \pm 7,7$ & $60,8 \pm 4,0 * *$ & $29,8 \pm 2,3$ & $13,6 \pm 1,1$ & $10,3 \pm 0,9 *$ \\
\hline 10.30 & контроль & $171,7 \pm 6,3$ & $96,0 \pm 7,6$ & $70,6 \pm 16,0$ & $34,2 \pm 2,3$ & $15,3 \pm 1,4$ & $7,9 \pm 0,5$ \\
\hline 11.00 & дослід & $215,1 \pm 8,2 * *$ & $96,7 \pm 8,6$ & $62,3 \pm 4,0$ & $31,9 \pm 2,5$ & $12,0 \pm 1,1$ & $9,5 \pm 0,7$ \\
\hline 11.00 & контроль & $168,3 \pm 6,3$ & $95,3 \pm 6,4$ & $85,4 \pm 8,0$ & $32,4 \pm 2,0$ & $14,7 \pm 1,2$ & $7,6 \pm 0,4$ \\
\hline 11.30 & дослід & $220,0 \pm 9,0 * * *$ & $99,8 \pm 8,5$ & $64,1 \pm 3,2 *$ & $31,5 \pm 2,5$ & $11,3 \pm 0,9 *$ & $8,9 \pm 0,5$ \\
\hline 11.30 & контроль & $163,1 \pm 6,3$ & $93,8 \pm 7,4$ & $81,1 \pm 7,0$ & $29,7 \pm 2,1$ & $15,3 \pm 1,3$ & $7,6 \pm 0,5$ \\
\hline 12.00 & дослід & $211,3 \pm 8,9 * *$ & $88,7 \pm 7,5$ & $58,1 \pm 2,0$ ** & $27,7 \pm 2,4$ & $12,2 \pm 1,1$ & $9,6 \pm 0,8$ \\
\hline 12.00 & контроль & $159,7 \pm 6,1$ & $90,4 \pm 6,5$ & $77,8 \pm 6,0$ & $27,2 \pm 2,0$ & $15,8 \pm 1,3$ & $7,9 \pm 0,6$ \\
\hline 12.30 & дослід & $205,2 \pm 6,4 * * *$ & $83,3 \pm 6,5$ & $56,2 \pm 2,3 * *$ & $26,3 \pm 3,0$ & $13,8 \pm 1,4$ & $9,9 \pm 0,8$ \\
\hline
\end{tabular}

Примітка. * $-\mathrm{p}<0,05 ; * *-\mathrm{p}<0,01 * * *-\mathrm{p}<0,001$ порівняно $з$ контролем.

Тобто в пробі жовчі, отриманій від самок щурів через 2,5 год після внутрішньопортального введення тамоксифену, концентрація таурохолевої кислоти більша від контрольного значення на $28,5 \%$ ( $<0,001)$. Зазначимо, що вплив тамоксифену на вміст таурохолату в жовчі подібний до раніше виявленого нами ефекту естрону на концентрацію таурохолату в жовчі самок щурів [1]. Концентрація глікохолевої кислоти в першій півгодинній пробі жовчі після внутрішньопортального введення тамоксифену становила $60,8 \pm 4,0$ мг \%, що на $34,3 \%(\mathrm{p}<0,01)$ менше, ніж у контролі $(92,5 \pm 8,0)$. Концентрація глікохолевої кислоти в останній півгодинній пробі жовчі після внутрішньопортального введення тамоксифену становила $56,2 \pm 2,3$ мг \%, а у тварин контрольної групи $77,8 \pm 6,0$ мг \%, тобто під впливом блокатора зменшувалася на $27,8 \%(\mathrm{p}<0,01)$, порівняно 3 контролем. Концентрація вільної тригідроксихоланової холевої кислоти статистично достовірно менша від контрольних значень тільки в третій півгодинній пробі жовчі. У першій півгодинній пробі жовчі після внутрішньопортального введення тамоксифену виявлено статистично значуще збільшення концентрації дигідроксихоланових хенодезоксихолевої та дезоксихолевої кислот. Надалі впродовж усього гострого досліду цей показник статистично значимо не змінювався (табл. 1).

Для з'ясування дії тамоксифену на кон'югацію та гідроксилювання жовчних кислот у гепатоцитах самок щурів розраховано відповідні коефіцієнти. Під впливом тамоксифену коефіцієнт кон'югації жовчних кислот статистично значимо не відрізнявся від контрольних величин (табл. 2). 
Коефіціснти кон'югації та гідроксилювання жовчних кислот у самок щурів після введення тамоксифену $(57,2$ мкг/100 г), $(M \pm S D ; n=11)$

\begin{tabular}{|c|c|c|c|}
\hline \multicolumn{2}{|c|}{ Півгодинні проміжки досліду, час } & Коефіціснт кон'югації & $\begin{array}{c}\text { Коефіціснт } \\
\text { гідроксилювання }\end{array}$ \\
\hline \multirow{2}{*}{$10.00-10.30$} & контроль & $17,56 \pm 2,29$ & $2,00 \pm 0,08$ \\
\cline { 2 - 4 } & дослід & $17,52 \pm 2,24$ & $2,02 \pm 0,06$ \\
\hline \multirow{2}{*}{$10.30-11.00$} & контроль & $16,80 \pm 2,47$ & $1,86 \pm 0,14$ \\
\cline { 2 - 4 } & дослід & $20,03 \pm 2,52$ & $2,02 \pm 0,10$ \\
\hline \multirow{2}{*}{$11.00-11.30$} & контроль & $17,70 \pm 2,16$ & $2,12 \pm 0,07$ \\
\cline { 2 - 4 } & дослід & $21,55 \pm 2,50$ & $1,96 \pm 0,07$ \\
\hline \multirow{2}{*}{$11.30-12.00$} & контроль & $16,98 \pm 1,61$ & $2,31 \pm 0,13 *$ \\
\cline { 2 - 4 } & дослід & $18,75 \pm 2,44$ & $1,98 \pm 0,07$ \\
\hline \multirow{2}{*}{$12.00-12.30$} & контроль & $16,61 \pm 1,53$ & $2,35 \pm 0,16$ \\
\cline { 2 - 4 } & дослід & $16,50 \pm 2,00$ & \\
\hline
\end{tabular}

Примітка. * - $<00,05$ порівняно з контролем.

Натомість коефіцієнт гідроксилювання жовчних кислот у самок, які отримали тамоксифен, виявився вищим, порівняно з контролем. У передостанній пробі жовчі коефіцієнт гідроксилювання становив $2,31 \pm 0,13$, що на $17,9 \%$ (p<0,05) більше, ніж у контрольному зразку жовчі (табл. 2$)$.

Продуктивні можливості печінки самок після одноразового внутрішньопортального введення тамоксифену в гострому досліді суттєво не змінилися, порівняно з контролем (табл. 3).

Таблиия 3

Інтенсивність секреції жовчних кислот із жовчю печінкою самок щурів після введення тамоксифену (8 мкг/100 г), $(M \pm S t D, n=12)$

\begin{tabular}{|c|c|c|c|c|c|c|c|}
\hline \multicolumn{2}{|c|}{$\begin{array}{l}\text { Півгодинні } \\
\text { проміжки досліду }\end{array}$} & $\begin{array}{c}\text { Таурохолева } \\
\text { кислота }\end{array}$ & $\begin{array}{c}\text { Таурохено- } \\
\text { дезоксихолева } \\
\text { й тауродезокси- } \\
\text { холева кислоти }\end{array}$ & $\begin{array}{c}\text { Глікохолева } \\
\text { кислота }\end{array}$ & $\begin{array}{c}\text { Глікохено- } \\
\text { днзоксихолева } \\
\text { й глікодезокси- } \\
\text { холева кислоти }\end{array}$ & $\begin{array}{c}\text { Холева } \\
\text { кислота }\end{array}$ & $\begin{array}{c}\text { Хенезокси- } \\
\text { холева } \\
\text { йдезоксихо- } \\
\text { лева кислоти }\end{array}$ \\
\hline $10.00-$ & контроль & $0,51 \pm 0,04$ & $0,29 \pm 0,08$ & $0,27 \pm 0,03$ & $0,10 \pm 0,01$ & $0,05 \pm 0,02$ & $0,02 \pm 0,006$ \\
\cline { 2 - 8 } 10.30 & дослід & $0,58 \pm 0,22$ & $0,27 \pm 0,10$ & $0,17 \pm 0,06$ & $0,08 \pm 0,03$ & $0,05 \pm 0,03$ & $0,04 \pm 0,02$ \\
\hline $10.30-$ & контроль & $0,48 \pm 0,03$ & $0,27 \pm 0,03$ & $0,24 \pm 0,03$ & $0,10 \pm 0,007$ & $0,04 \pm 0,01$ & $0,02 \pm 0,005$ \\
\cline { 2 - 8 } 11.00 & дослід & $0,60 \pm 0,26$ & $0,26 \pm 0,10$ & $0,17 \pm 0,07 *$ & $0,09 \pm 0,03$ & $0,04 \pm 0,03$ & $0,03 \pm 0,02$ \\
\hline $11.00-$ & контроль & $0,43 \pm 0,05$ & $0,29 \pm 0,10$ & $0,22 \pm 0,02$ & $0,08 \pm 0,009$ & $0,05 \pm 0,02$ & $0,02 \pm 0,01$ \\
\cline { 2 - 8 } 11.30 & дослід & $0,58 \pm 0,21$ & $0,25 \pm 0,08$ & $0,16 \pm 0,06$ & $0,08 \pm 0,02$ & $0,03 \pm 0,02$ & $0,03 \pm 0,01$ \\
\hline $11.30-$ & контроль & $0,40 \pm 0,06$ & $0,23 \pm 0,04$ & $0,20 \pm 0,02$ & $0,07 \pm 0,01$ & $0,04 \pm 0,01$ & $0,02 \pm 0,005$ \\
\cline { 2 - 8 } 12.00 & дослід & $0,59 \pm 0,16$ & $0,25 \pm 0,08$ & $0,16 \pm 0,04$ & $0,07 \pm 0,01$ & $0,03 \pm 0,02$ & $0,03 \pm 0,01$ \\
\hline \multirow{2}{*}{$\begin{array}{c}12.00- \\
12.30\end{array}$} & контроль & $0,39 \pm 0,07$ & $0,22 \pm 0,05$ & $0,19 \pm 0,04$ & $0,07 \pm 0,02$ & $0,04 \pm 0,01$ & $0,02 \pm 0,005$ \\
\cline { 2 - 8 } & дослід & $0,42 \pm 0,12$ & $0,17 \pm 0,03$ & $0,11 \pm 0,03 * *$ & $0,05 \pm 0,02$ & $0,03 \pm 0,02$ & $0,02 \pm 0,01$ \\
\hline
\end{tabular}

Примітка. ${ }^{*}-\mathrm{p}<0,05, * *-\mathrm{p}<0,01$, порівняно з контролем.

Отримана нами динаміка інтенсивності секреції більшості кон'югованих і вільних холатів подібна до такої в контролі. Концентрація таурохолевої кислоти та хенодезоксихолевої й дезоксихолевої кислот у жовчі самок після введення тамоксифену збільшується, а концентрація глікохолевої й холевої кислот - навпаки, зменшується. Виявлена при цьому відсутність статистично значущих змін інтенсивності секреції зазначених холатів може бути обумовлена пригніченням надходження води до жовчних канальців при дії тамоксифену. Таке припущення можливе 3 огляду на можливість залучення каналікулярних водних каналів гепатоцитів aquaporin-8 (AQP8) до розвитку естроген-залежного холестазу. Тільки інтенсивність секреції глікохолевої кислоти статистично значуще зменшується після введення тамоксифену (табл. 3), що збігається зі значним зниженням її концентрації у відповідних пробах жовчі (табл. 1).

Висновки та перспективи подальшого дослідження. Блокада естрогенових рецепторів за допомогою одноразового внутрішньопортального введення тамоксифену робить неможливим регу- 
ляторний вплив ендогенних естрогенів на секрецію холатів у первинні жовчні канальці. Одноразове введення тамоксифену в гострому досліді призводить до суттєвих змін продуктивних можливостей печінки, що відображається в зміні жовчнокислотного спектра печінкового секрету. Такі швидкі ефекти блокатора не можуть бути обумовлені лише унеможливленням дії на відповідні рецептори ендогенних естрогенів. Найзначніший вплив тамоксифен виявляв щодо механізмів, які забезпечують утворення, трансцелюлярний і трансканалікулярний транспорт глікохолату, що спричиняє пригнічення надходження в жовч самок щурів глікохолевої кислоти.

\section{Джерела та література}

1. Климюк О. В. Особливості жовчоутворення у щурів різної статі за дії естрону / О. В. Климюк, О. В. Бондзик, Є. М. Решетнік [та ін.] // Фізіол. журн. - 2011. - Т. 57, № 6. - С. 52-57.

2. Весельский С. П. Способ определения желчных кислот в биологических жидкостях / С. П. Весельский, П. С. Лященко, И. А. Лукьяненко // Авторское свидетельство. № 1624322. Опубл. 30.01.1991 г. Бюл. № 4.

3. Філімонова Н. Б. Статистичний аналіз даних відповідно до засад науково обгрунтованої медицини. Первинний аналіз кількісних даних, подання результатів експерименту / Н. Б. Філімонова, І. О. Філь, Т. С. Михайлова // Медицина залізничного транспорту України. - 2004. - № 4. - С. 30-38.

4. Філімонова Н. Б. Статистичний аналіз даних відповідно до засад науково обгрунтованої медицини. Порівняння груп за кількісними показниками / Н. Б. Філімонова, І. О. Філь // Медицина транспорту України. - 2005. - № 4. - С. 86-93.

5. Becker C. Another Selective Estrogen-Receptor Modulator for Osteoporosis / C. Becker // N. Engl J Med. - 2010. V 362. - P. 752-754.

6. Chen J. Estrogen-induced cholestasis: pathogenesis and therapeutic implications / J. Chen, K. N. Zhao, G. B. Liu // Hepatogastroenterology. - 2013. - V. 60(126). - P.1289-1296.

7. Dhiman R. K. Is there a link between oestrogen therapy and gallbladder disease? / R. K. Dhiman, Y. K. Chawla // Expert Opin Drug Saf. - 2006. - V. 5(1). - P. 117-129.

8. Everson G. T. Mechanisms of gallstone formation in women. Effects of exogenous estrogen (Premarin) and dietary cholesterol on hepatic lipid metabolism / G. T. Everson, C. Mc Kinley, F. Kern // Journal of Clinical Investigation. - 1991. - V. 87(1). - P. 237-246.

9. Feng Y. Cloning of a novel member of the G protein-coupled receptor family related to peptide receptors / Y. Feng, P. Gregor // Biochemical and Biophysical Research Communications. - 1997. - V. 231(3). - P. 651-654.

10. Fisher B. Tamoxifen for prevention of breast cancer: current status of the National Surgical Adjuvant Breast and Bowel Project P-1 study / B. Fisher, J. P. Costantino, D. L. Wickerham [et al.] // J Natl Cancer Inst. - 2005. V. 97. - P. 1652-1662.

11. Gruber C. J. Production and actions of estrogens / C. J. Gruber, W. Tschugguel, C. Schneeberger, J. C. Huber // The New England Journal of Medicine. - 2002. - V. 346(5). - P. 340-352.

12. Hsieh Y.-C. G-Protein-Coupled Receptor 30-Dependent Protein Kinase A Pathway Is Critical in Nongenomic Effects of Estrogen in Attenuating Liver Injury after Trauma-Hemorrhage / Y.-C. Hsieh, H.-P. Yu, M. Frink, T. Suzuki, M.-G. Choudhry [et al.] // The American Journal of Pathology. - 2007. - V. 170. - Issue 4. - P. 1210-1218.

13. Iavarone $\mathrm{M}$. The clinical and pathogenetic significance of estrogen receptor-P expression in chronic liver diseases and liver carcinoma / M. Iavarone, P. Lampertico, C. Seletti [et al.] // Cancer. - 2003. - V. 98(3). - P. 529-534.

14. Khan M. K.. Pregnancy causing gallstone disease / M. K. Khan, M. A. Jalil, S. U. Khan // Mymensingh Med. J. 2008. - V. 17, Suppl 2. - P. S. 91. - S.96.

15. Marrone J. Adenoviral transfer of human aquaporin-1 gene to rat liver improves bile flow in estrogen-induced cholestasis / J. Marrone, G. L. Lehmann, L. R. Soria [et al.] // Gene Ther. - 2014. - V. 21(12). - P. 1058-1064.

16. Novacek G. Gender and gallstone disease / G. Novacek // Wien Med Wochenschr. - 2006. - V. 156 (19-20). P. 527-533.

17. Portincasa P. Coordinate regulation of gallbladder motor function in the gut-liver axis / P. Portincasa, A. Di Ciaula, H. H. Wang [et al.] // Hepatology. - 2008. - V. 47(6). - P. 2112-2126.

18. Prossnitz E. R. GPR30: A G protein-coupled receptor for estrogen / E. R. Prossnitz, J. B. Arterburn, L. A. Sklar // Molecular and Cellular Endocrinology. - 2007. - V. 265-266. - P. 138-142.

19. Prossnitz E. R. Estrogen Signaling through the Transmembrane G Protein-Coupled Receptor GPR30 / E. R. Prossnitz, J. B. Arterburn, H. O. Smith, T. I. Oprea, L. A. Sklar [et al.] // Annual Review of Physiology. - 2008. - V. 70. P. $165-190$.

20. Zucchetti A. E. Hormonal modulation of hepatic cAMP prevents estradiol $17 \beta$-D-glucuronide-induced cholestasis in perfused rat liver / A. E. Zucchetti, I. R. Barosso, A. C. Boaglio [et al.] // Dig Dis Sci. - 2013. - V. 58(6). P. 1602-1614.

Боровець Оксана, Бенедь Владимир, Решетник Евдокия, Весельский Станислав, Макарчук Николай. Жовчносекреторная функция печени самок крыс в условиях блокады эстрогенных рецепторов та- 
моксифеном. В острых опытах на крысах - самках с канюлированным желчным протоком, которые находились под тиопенталовым наркозом (5 мг / 100 г), исследовано влияние тамоксифена (57,2 мкг / 100 г) при его однократном внутрипортальном введении на желчесекреторную функцию печени. С помощью тонкослойной хроматографии определена концентрация желчных кислот (свободных и коньюгированных с таурином и глицином ) в полученных в течение острых опытов пяти получасовых пробах желчи.

Ключевые слова: желчь, желчные кислоты, печень, эстрогеновые рецепторы, тамоксифен.

Borovets Oksana, Bened' Volodymyr, Reshetnik Evdokiay, Veselsky Stanislav, Makarchuk Mykola. Bile Secretion Liver Function in the Female Rats at Estrogen Receptor Tamoxifen Blockade Conditions. Influence of tamoxifen $(57,2 \mathrm{mkg}$ per $100 \mathrm{~g}$ of body weight) on secretion of bile and bile acids was studied in acute experiments in female rats. The concentration of bile acids (taurocholic acid, taurochenodeoxycholic and taurodeoxycholic acids, glycocholic acid, glycochenodeoxycholic and glycodeoxycholic acids, cholic acid, chenodeoxycholic and deoxycholic acids) were determine in six samples of bile using thin layer chromatography. Tamoxifen effects on nuclear estrogen receptors. Concentration decreasing of glycocholic acid $(27,8-34,3 \%, \mathrm{p}<0,01)$ and cholic acid were observed in female rats bile while such of taurocholic acid increased $(16,8-30,7 \%(p<0,05)$. Tamoxifen caused significant changes in the biotransformation and biosynthesis of bile acids in the liver of the experimental female animals, as reflected by changes in the ratio of trihydroxycholic and dihydroxycholic acids. Thus, tamoxifen influencing metabolism and transport of bile acids does not increase its lithogenic characteristics.

Key words: bile, bile acids, liver, estrogen receptors, tamoxifen.

Стаття надійшла до редколегії 29.01.2016 p. 